\title{
Removal of Phenol Using Spore Forming Bacillus AB011 Isolated from Waste Water Treatment Plant
}

\section{Majdah Mohamed Ahmed Aburas}

Biology Department, Faculty of Science, King Abdulaziz University, Jeddah, KSA

Email: velvetmsfs@gmail.com

How to cite this paper: Aburas, M.M.A. (2016) Removal of Phenol Using Spore Forming Bacillus ABO11 Isolated from Waste Water Treatment Plant. Advances in Microbiology, 6, 898-908.

http://dx.doi.org/10.4236/aim.2016.612084

Received: August 19, 2016

Accepted: October 15, 2016

Published: October 18, 2016

Copyright $\odot 2016$ by author and Scientific Research Publishing Inc. This work is licensed under the Creative Commons Attribution-NonCommercial International License (CC BY-NC 4.0). http://creativecommons.org/licenses/by-nc/4.0/ (c) (i) (8) Open Access

\begin{abstract}
Twenty isolates of bacteria were isolated from contaminated wastewater collected from wastewater treatment station, used to clean the raw sewage at Jeddah on minimal medium containing phenol $(0.5 \mathrm{~g} / \mathrm{l})$ as carbon source while at $0.6 \mathrm{~g} / \mathrm{l}$ phenol, five isolates belonging to Gram positive and Gram negative bacteria were obtained after 10 days of growth at $37^{\circ} \mathrm{C}$. All the tested bacteria were tested for phenol degradation in liquid medium and isolate $\mathrm{ABO} 11$ was the most active isolate in phenol degradation. It was selected and tested for the ability to use phenol as carbon and energy source. It was identified as Bacillus sterothermophilus ABO11 using morphological and biochemical tests. Genetic studies confirmed the identification. Bacterial growth and phenol degradation by the selected bacterium were determined using different initial phenol concentrations $(0-1.0 \mathrm{~g} / \mathrm{l})$. Very weak growth was recorded at $0.8 \mathrm{~g} / \mathrm{l}$ and no growth or degradation was observed at higher phenol concentration. The isolate was adapted to grow in presence of $0.8 \mathrm{~g} / \mathrm{l}$ phenol and phenol degradation was checked up to 12 days of growth. Percentage of degradation was $100 \%$ after 10 days. Maximum growth was observed at $40^{\circ} \mathrm{C}$, $\mathrm{pH} 8$ and using $\mathrm{NH}_{4} \mathrm{Cl}$ as nitrogen source. In conclusion, the selected isolate, Bacillus sterothermophilus $\mathrm{ABO} 11$ can be used in protecting the environment from phenol pollution.
\end{abstract}

\section{Keywords}

Phenol, Degradation, Bacteria, Wastewater, Assay, Bacillus

\section{Introduction}

Phenolic compounds contained a hydroxyl group $(\mathrm{OH})$ directly attached to aromatic cycle and phenol $\left(\mathrm{C}_{6} \mathrm{H}_{5} \mathrm{OH}\right)$ is the simplest compounds in the environment that are 
widely distributed as pollutants [1] [2]. Each year, millions of tones of phenol are produced for the production of plastics and caprolactam, used for nylon and synthetic fibers [3]. Phenolic compounds are detected in ground water, waste water and in effluents of much industrial waste water [4]. Nowadays, degradation of phenol is of great importance due to their toxicity and high solubility. These compounds are contaminants in environmental matrices, food, and medicine products that can easily be absorbed through humans and animals' skin or mucous membranes. Phenols significantly inhibit microbial activity due to membrane damage at higher phenol concentrations [5] [6] and toxicity to biological treatment systems and bacterial cell disruption were observed in high phenol concentrations. In the environment, phenol can be aerobically degraded to catechol using a single microbe or a combination of microorganisms like Trichosporon cutaneum [7], Brevibacterium fuscum [8], Hormodendrum bergeri, Fusarium oxysporum and Aspergillus flavus var. coulmnaris [9]. The aims of this investigation were to isolate, characterize and identify a bacterial isolate with potential activity for phenol degradation from waste water effluents.

\section{Materials and Methods}

\subsection{Bacterial Isolation}

Row waste water samples were collected from different Wastewater Station at Jeddah and bacteria was isolated on minimal salt medium containing $0.5 \mathrm{~g} / \mathrm{l}$ phenol. The minimal salt medium was composed of $(\mathrm{g} / \mathrm{l}): \mathrm{NH}_{4} \mathrm{Cl}, 2.1 ; \mathrm{K}_{2} \mathrm{HPO}_{4}, 4.35 ; \mathrm{KH}_{2} \mathrm{PO}_{4}, 1.7$; $\mathrm{MgSO}_{4} \cdot 7 \mathrm{H}_{2} \mathrm{O} 0.2 ; \mathrm{CaCl}_{2} \cdot 2 \mathrm{H}_{2} \mathrm{O} 0.03 ; \mathrm{MnSO}_{4}, 0.05$ and $\mathrm{CaCl}_{2} \cdot \mathrm{H}_{2} \mathrm{O}, 0.03$. Agar, 20 g, were added for solid medium preparation. All the previous material was added to $1000 \mathrm{ml}$ double distilled water and $0.5 \mathrm{~g} / \mathrm{l}$ of phenol was added. Agar plates were inoculated with $0.1 \mathrm{ml}$ of the waste water and all plated were incubated at $37^{\circ} \mathrm{C}$ for 7 days. The growth, cell shapes and Gram reaction of all obtained isolated were detected. All the isolates were selected and purified on nutrient agar plates and pure isolates were stored on LB agar slant at $37^{\circ} \mathrm{C}$ until further use.

\subsection{Growth in Phenol Containing Broth Medium}

All the obtained isolated were grown in nutrient broth medium for 2 days at $37^{\circ} \mathrm{C}$ (preculture). All the isolates were screened in $250 \mathrm{ml}$ flask containing $50 \mathrm{ml}$ of minimal salt broth medium containing phenol $(0.8 \mathrm{~g} / \mathrm{l})$ as sole source of carbon and with $2 \mathrm{ml}$ of the preculture of the tested bacterium $\left(2 \times 10^{6} \mathrm{cfu} / \mathrm{ml}\right)$. All inoculated flasks were incubated at $37^{\circ} \mathrm{C}$ on rotary shaking incubator at $120 \mathrm{rpm}$ for 7 days [10]. Finally, growth of cells was determined by turbidity measurement at $600 \mathrm{~nm}$ and $\%$ of phenol degradation was determined after 7 days. Medium containing all components without bacterial inoculums was used as control.

\subsection{Selection and Adaptation of the Best Phenol Degraded Isolate}

Isolate $\mathrm{ABO} 11$ was selected for adaptation for phenol degradation in $250 \mathrm{ml}$ flask containing $50 \mathrm{ml}$ of minimal salt broth medium, contained $0.1 \mathrm{~g} / \mathrm{l}$ and $5 \mathrm{ml}$ of enriched 
media was transferred to $45 \mathrm{ml}$ of new prepared medium, containing subsequently increased content of phenol $(0.1-1 \mathrm{~g} / \mathrm{l})$, each 5 days. All flasks were incubated at $37^{\circ} \mathrm{C}$ at $120 \mathrm{rpm}$. The growth was detected by spreading $0.1 \mathrm{ml}$ of the culture on NA medium.

\subsection{Bacterial Growth in Liquid Medium}

Isolate $\mathrm{ABO} 11$ was grown in $250 \mathrm{ml}$ flask containing $48 \mathrm{ml}$ of minimal salt broth medium, contained $0.8 \mathrm{~g} / \mathrm{l}$ phenol and inoculated with $2 \mathrm{ml}$ of the preculture $\left(2 \times 10^{6}\right.$ $\mathrm{cfu} / \mathrm{ml}$ ) of the bacterial isolate. All flasks were incubated at $37^{\circ} \mathrm{C}$ at $120 \mathrm{rpm}$ and the growth (A $600 \mathrm{~nm}$ ) and phenol concentration were determined and compared with control (uninoculated broth medium). $\%$ of phenol degradation was calculated.

\subsection{Best Conditions for Phenol Degradation}

Effect of different temperatures $\left(20^{\circ} \mathrm{C}-50^{\circ} \mathrm{C}\right)$ and $\mathrm{pH}$ values on bacterial growth were determined in minimal salt broth medium after 10 days of growth at $120 \mathrm{rpm}$. Effect of different nitrogen source were determined in the previous medium in which nitrogen source was replaced with Peptone, yeast extract, $\mathrm{NaNO}_{3}$ and valine at concentration of $2 \mathrm{~g} / \mathrm{l}$. The used positive control was $\mathrm{NH}_{4} \mathrm{Cl}_{4}$. After 10 days at $40^{\circ} \mathrm{C}$, bacterial growth was determined by the absorbance at $600 \mathrm{~nm}$.

\subsection{Identification of the Best Phenol Degraded Isolate}

The selected bacterium $\mathrm{ABO} 11$ was streaked on nutrient agar plates, incubated at $37^{\circ} \mathrm{C}$ and examined for colony shape, Gram reaction and cell morphology using light and electron microscopes. Some biochemical tests including esculin, Tween 80, lecithin and starch hydrolysis, utilization of casein and gelatin liquefaction were determined. Identification was carried out according to Bergey's manual of determinative of bacteriology [11] and Sivaraj et al. [12]. Molecular studies and phylogenetic analysis of $16 \mathrm{~S}$ rDNA sequence of the isolate ABO11 was carried out as described by Tork et al. [13] and Aly et al. [14]. ABO11 genomic DNA was isolated using QIAamp DNA Mini Kit and the 16S rDNA gene was amplified by polymerase chain reaction technique [15]. The forward primer 5' AGTTTGATCATGGTCAG-3' and reverse primer 5'-GGTTACCTTGTTACGACT 3' were used and the purified PCR products was sequenced using big dye terminator cycle sequence kit, analyzed using DNA sequence ABI PRISM 310 genetic analyzer (Perkin Elmer, USA) and compared to the GeneBank [13].

\subsection{Phenol Assay}

The residual amount of phenolic compounds present in the sample at different incubation period was measured by colorimetric assay 4-amino antipyrine method [16]-[18].

\section{Results}

This study was focused on isolation and evaluation of the capability of bacteria, isolated from heavily polluted water, for phenol degradation. Row wastewater samples were collected from wastewater treatment station, used to clean the raw sewage, for bacterial 
isolation on minimal salt agar medium, containing phenol $(0.5 \mathrm{~g} / \mathrm{l})$ as carbon source. Twenty different bacterial isolates were obtained and screened on minimal salt agar medium, containing phenol $(0.6 \mathrm{~g} / \mathrm{l})$. Five isolates belonging to Gram positive and Gram negative bacteria were obtained after 10 days of growth at $37^{\circ} \mathrm{C}($ Table 1$)$. All the tested bacteria were tested for phenol degradation in liquid minimal salt medium. The bacterial growth $(\mathrm{A} 600 \mathrm{~nm})$ in phenol containing medium was ranged from $0.22-0.52$ and percentage of phenol degradation was ranged from $46 \%-100 \%$. The isolate $\mathrm{ABO} 11$ was the most active isolate in phenol degradation where no phenol concentration was recorded on the medium while isolate $\mathrm{ABO} 1$ showed the highest growth. The most active isolate $\mathrm{ABO} 11$ in phenol degradation was selected and tested for the ability to use phenol as carbon and energy source at higher concentrations. It was identified as $\mathrm{Ba}$ cillus sterothermophilus $\mathrm{ABO} 11$ using morphological and biochemical tests (Table 2). It was Gram positive, spore forming bacilli, has creamy color and regular colonies. It has no capsule or cyst. Hydrolysis of lecithin, tween 80 and esculin were negative while starch hydrolysis was positive (Table 2). Utilization of casein was positive while gelatin liquefaction was negative. Moreover, resistance to Ampicillin was negative. Genetic studies confirmed the identification (Figure 1). Bacterial growth and phenol degradation by the selected bacterium was determined using different initial phenol concentration $(0-1.0 \mathrm{~g} / \mathrm{l})$. Very weak growth was recorded at $0.8 \mathrm{~g} / \mathrm{l}$ and no growth or degradation was observed at higher concentration (Figure 2). The isolate was adapted to grow

Table 1. Growth and phenol degradation of the isolated bacteria from waste water on solid and in broth media.

\begin{tabular}{ccccccc}
\hline \multirow{2}{*}{ Bacterial isolate } & Source of & \multicolumn{3}{c}{ Solid medium } & & \multicolumn{2}{c}{ Liquid medium } \\
\cline { 3 - 7 } & isolation & Cell shape & $\begin{array}{c}\text { Gram } \\
\text { reaction }\end{array}$ & Growth & Growth & \% phenol degradation \\
\hline ABO1 & Waste water & Bacilli & Negative & ++ & 0.52 & 90 \\
ABO7 & Waste water & Cocci & Negative & + & 0.22 & 74 \\
ABO9 & Waste water & Cocci & Positive & + & 0.38 & 69 \\
QBO10 & Waste water & Bacilli & Negative & + & 0.29 & 46 \\
ABO11 & Waste water & Bacilli & Positive & ++ & 0.41 & 100 \\
\hline
\end{tabular}

++ : moderate growth, +: poor growth.

Table 2. The morphological and biochemical characters of the isolate $\mathrm{ABO} 11$.

\begin{tabular}{cccc}
\hline Character & Result & Character & Result \\
\hline Gram stain & Positive & Gelatin liquefaction & - \\
Acid fast & Negative & Hydrolysis of esculin & - \\
Shape & Bacilli & Hydrolysis of Tween 80 & - \\
Color & Creamy & Egg yolk lecithin & + \\
Colonies & Regular & Hydrolysis of starch & - \\
Colony edge & Entire & Hemolysis & + \\
Endospore & + & Utilization of casein & - \\
Cyst, capsule & - & Resistance to Ampicillin & \\
\hline
\end{tabular}




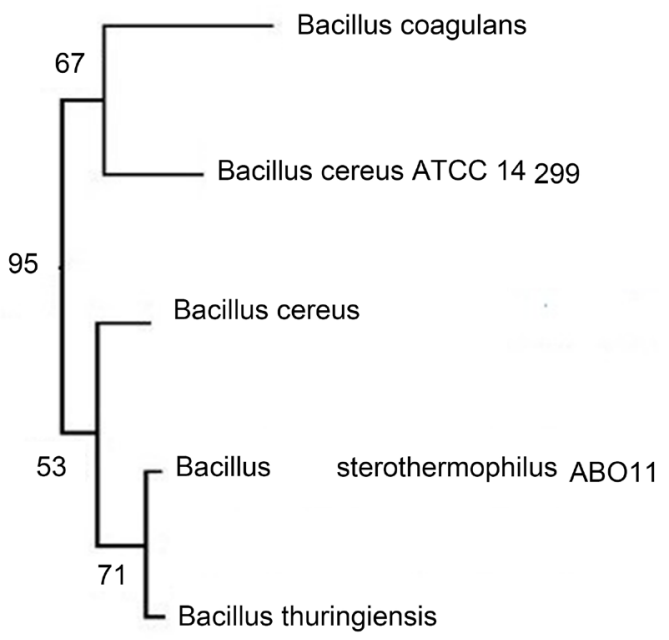

Figure 1. Phylogenetic tree based on $16 \mathrm{~S}$ rDNA sequence comparisons of Bacillus sterothermophilus $\mathrm{ABO} 11$, using neighbor joining tree method, maximum sequence difference $=0.002$.

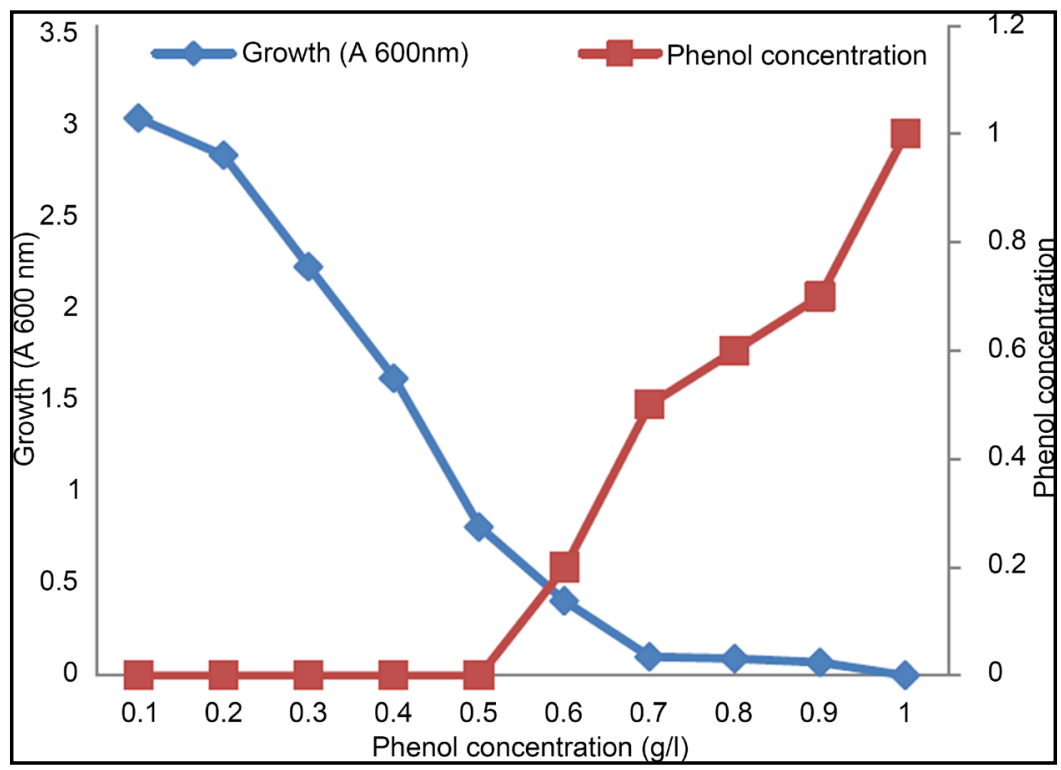

Figure 2. Effect of different concentration of phenol on bacterial growth of the isolate ABO11.

in presence of $0.8 \mathrm{~g} / \mathrm{l}$ phenol and phenol degradation was checked up to 12 days of growth (Figure 3 and Figure 4). Increasing time, increased growth and phenol degradation and percentage of degradation was $100 \%$ after 10 days and negligible decrease was observed in phenol concentration in control sample. Maximum growth of the selected isolate, Bacillus sterothermophilus $\mathrm{ABO} 11$ in minimal salt broth medium with $0.8 \mathrm{~g} / \mathrm{l}$ phenol as carbon source was observed at $40^{\circ} \mathrm{C}, \mathrm{pH} 8$ and using $\mathrm{NH}_{4} \mathrm{Cl}$ as nitrogen source (Figures 5-7).

\section{Discussion}

Bacteria have a major role in saving the environment by removing of toxic chemicals 


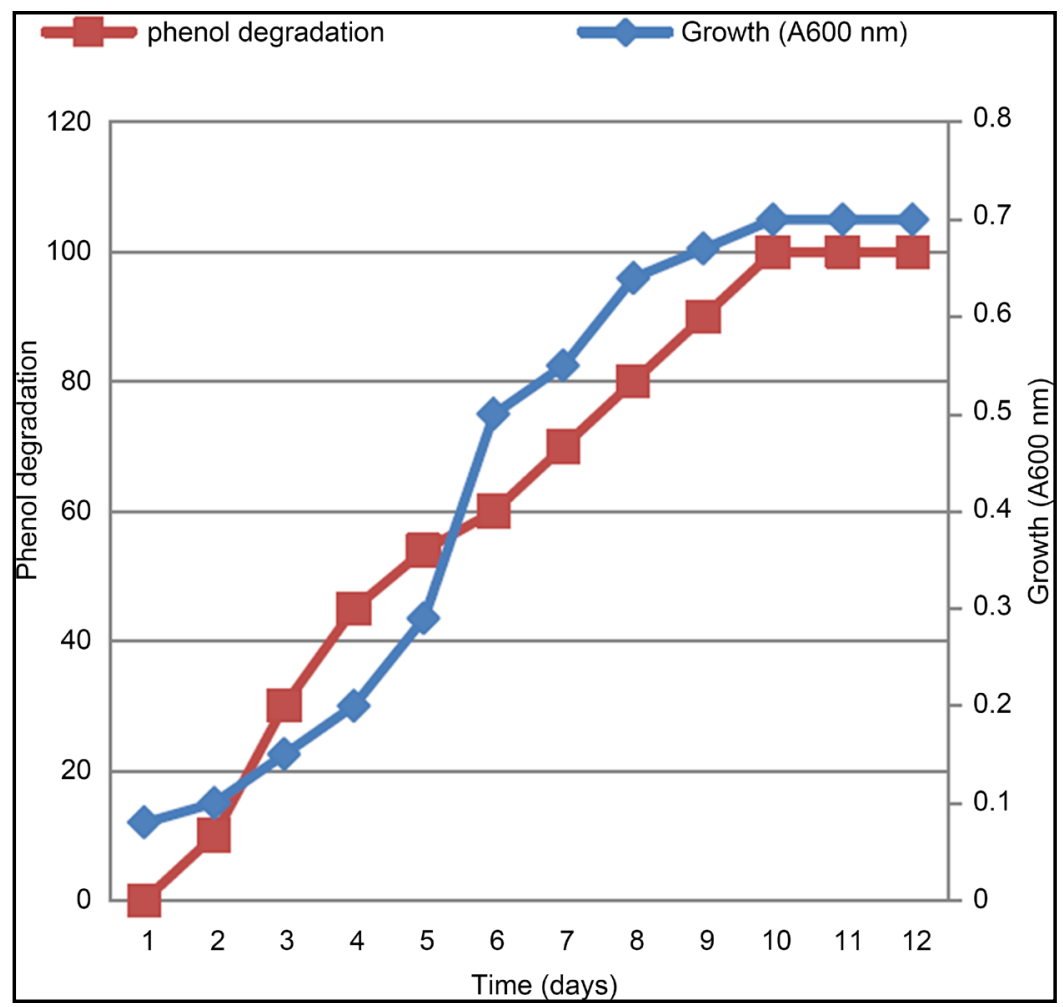

Figure 3. Growth of the isolate $\mathrm{ABO} 11$ and phenol degradation after 12 days at $37 \mathrm{C}, 120 \mathrm{rpm}$ in minimal medium containing $0.8 \mathrm{~g} / \mathrm{l}$ phenol as a carbon source.

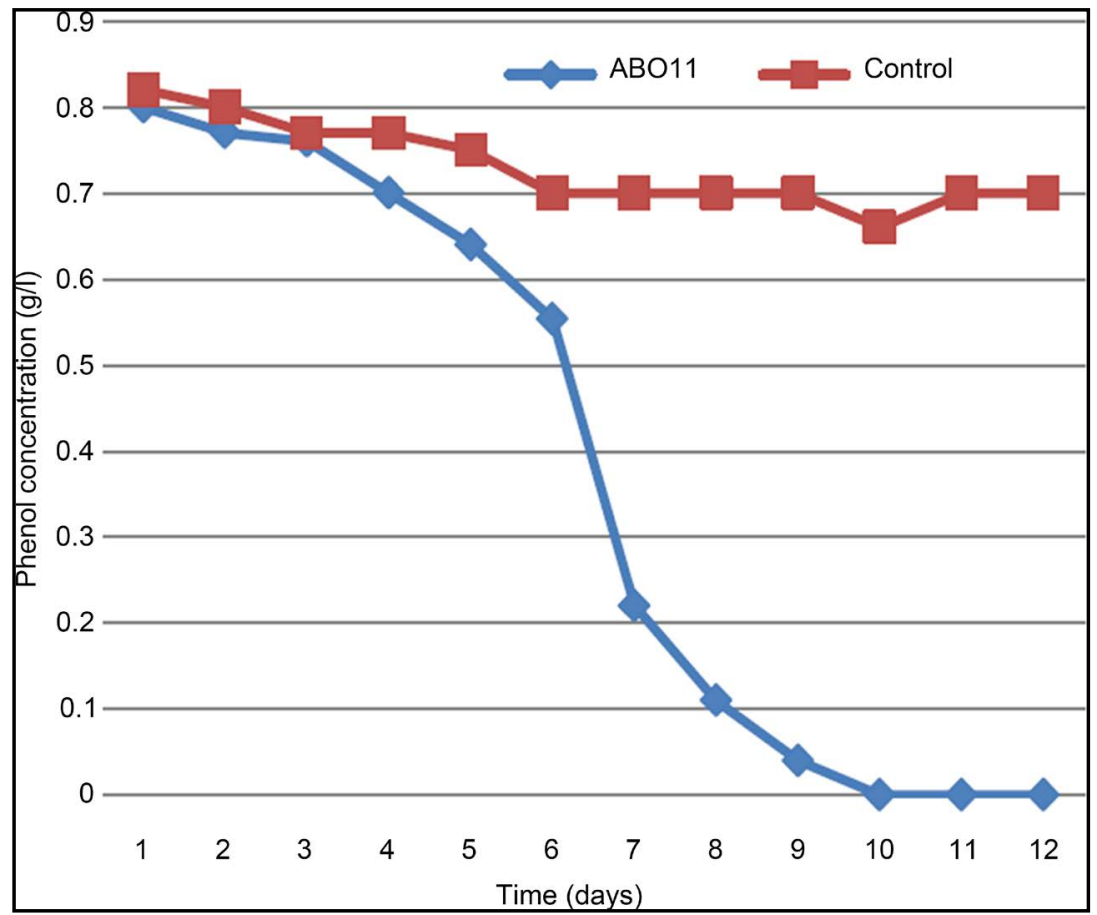

Figure 4. Phenol concentration recoded after the growth of the selected isolate ABO11 in medium containing phenol after 12 days and compared to control (non inoculated medium). 


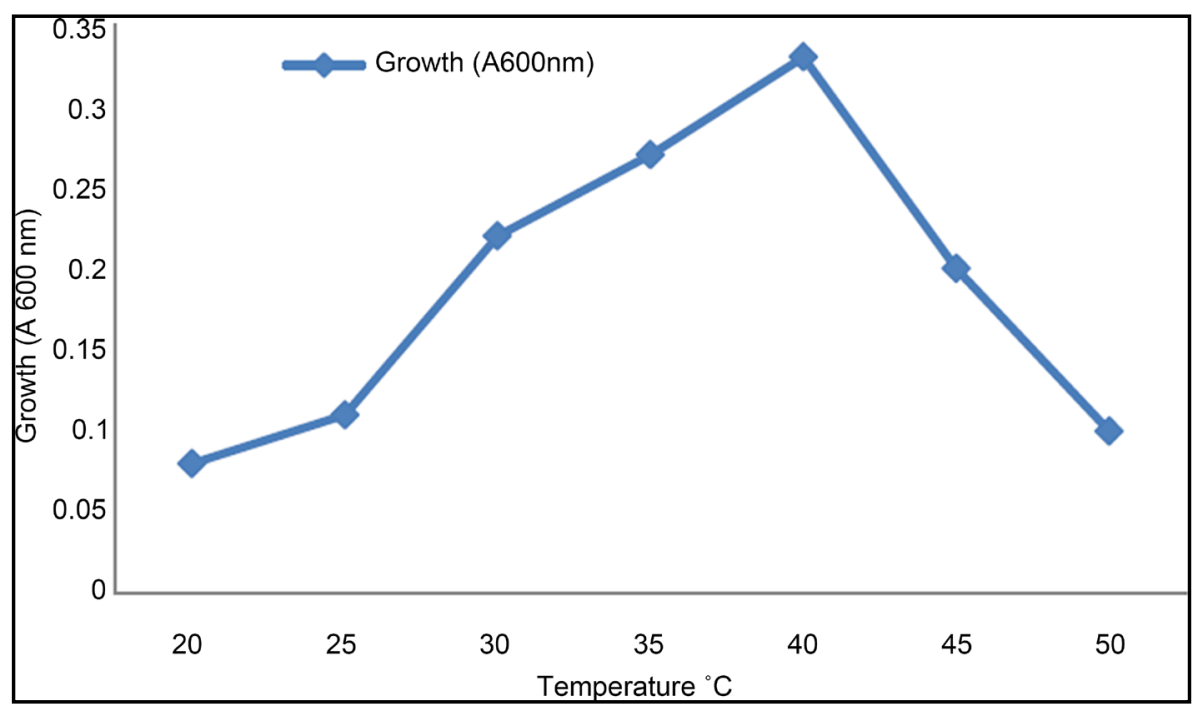

Figure 5. Growth of the selected isolate ABO11 in medium containing phenol for 10 days at different temperature.

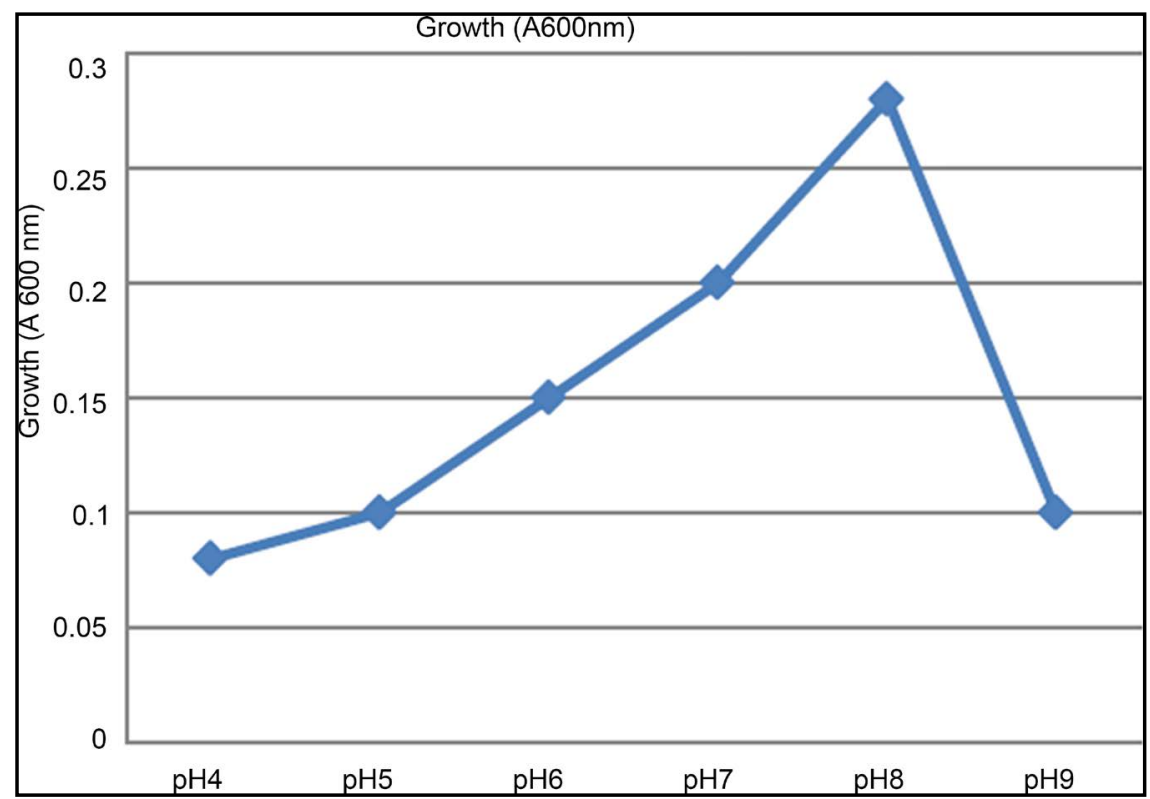

Figure 6. Growth of the selected isolate ABO11 in medium containing phenol for 10 days at different $\mathrm{pH}$ values.

and wastes that are harmful to human and animals. Many authors reported that bacteria or fungi can be effectively used for bioremediation of phenol in contaminated sites [9] [19]-[21]. Degradation intermediate compounds were also determined. Isolation of bacterial that degrade chemical compounds usually carried out from polluted water or soil. Phenol can cause serious problems in the wastewater treatment process, making phenol degradation a necessary step in the wastewater treatment process. This study was carried out for isolation of phenol degraded bacteria found in waste water. In a study of Mohite et al. [21], from a contaminated soil sample, aerobic Streptococcus 


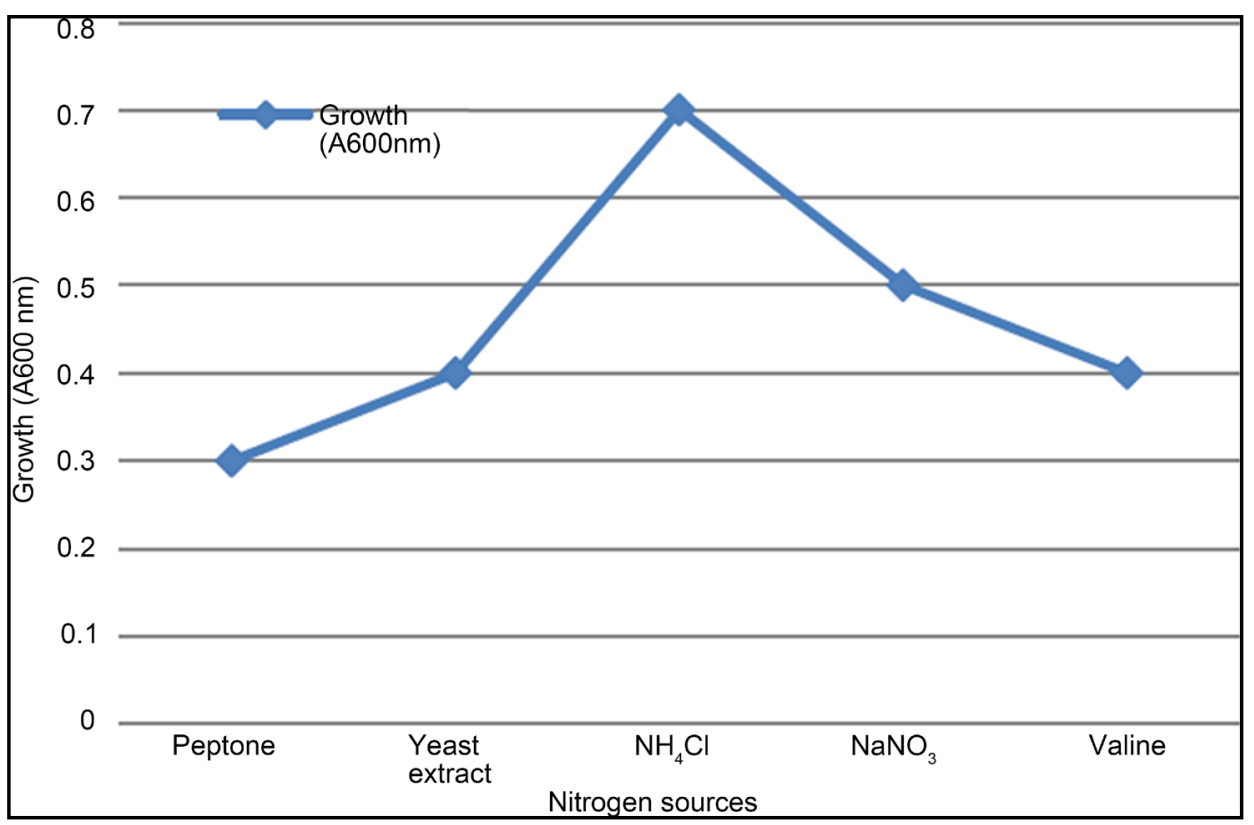

Figure 7. Growth of the selected isolate ABO11 in medium containing phenol for 10 days using different nitrogen sources.

epidermis was isolated using enrichment technique on medium containing phenol as carbon and energy source. Many bacterial strains were isolated in pure culture and selected for their ability to degrade phenol. The isolate ABO11 used $0.8 \mathrm{~g} / 1$ phenol in 10 days while lower degradation was obtained by Mohite et al. [21], who stated that their bacterial isolate was able to degrade phenol up to $200 \mathrm{mg} / \mathrm{l}$. As it was well known, phenol is oxidized to catechol by a phenol hydroxylase and catechol is further degraded using catechol 1,2-dioxygenase [22]. Phenotype and genotype characterization of isolated bacterium indicated that the most active isolate was a Gram-positive, motile and rod-shaped bacterium and belonged to genus Bacillus. Sequencing of the $16 \mathrm{~S}$ rDNA gene shared 95\% identity with that of genus Bacillus. The xenobiotics tolerant strain Bacillus sp. has been isolated from soils contaminated with xenobiotics and currently used for bioremediation [23]. Hasan and Jabeenb [24] obtained Pseudomonas sp. (IES-S) and Bacillus subtilis (IES-B) from contaminated area for malathion, cypermethrin and phenol degradation and they found that the isolates possess high phenol tolerance up to $400-700 \mathrm{mg} / \mathrm{l}$ phenol without any significant inhibition, hence could be used for phenol remediation, found in wastewaters.

Biodegradation of phenol by bacteria is widely applied for the degradation of phenolic compounds through a specific mechanism and at least two enzymes are involved in the process. Phenol and other phenolic compounds are common constituents of many industrial effluents which can be safely treated and disposed by microbial degradation [25]. From the effluent of the Exxon Mobile Oil Refinery waste water treatment and under aerobic condition, Candida tropicalis RETLCrl was isolated for phenol degradation [19] while degradation of phenol and some of its alkyl derivatives were found under both aerobic and anaecrobic conditions in seven Japanese soil samples [26]. 
Moreover, Klebsiella oxytoca degraded 75\% of initial phenol concentration (100 ppm) within $72 \mathrm{hr}$ [27]. Stimulation the growth conditions enhanced growth to degrade very high concentrations of phenol. In this study, the best growth in phenol containing medium was at $40^{\circ} \mathrm{C}$, pH 8 and using $\mathrm{NH}_{4} \mathrm{Cl}$ as nitrogen source which considered the simplest inorganic nitrogen source for bacterial growth and enzyme and protein synthesis. Actinobacillus species degraded phenol and achieving the higher growth and percentage of phenol degradation at $\mathrm{pH} 7$, incubation temperature of $35^{\circ} \mathrm{C}-37^{\circ} \mathrm{C}, 150 \mathrm{rpm}$ and using succinic acid and glycine as carbon and nitrogen source [28]. The phenol degradation could be further enhanced by the process of cell immobilization [29] [30]. The effective treatment of phenolic paper factory effluent was obtained using immobilized Alcaligenes sp. [31].

\section{Conclusion}

In conclusion, the selected isolate, Bacillus sterothermophilus $\mathrm{ABO} 11$ can be used in cleaning the environment from phenol pollution.

\section{References}

[1] IARC, International Agency for Research on Cancer (1989) Phenol. In: IARC Monographs on the Evaluation of the Carcinogenic Risk of Chemicals to Humans, World Health Organization, 47, 263-287.

[2] Wallace, J. (1996) Phenol. In: Kirk-Othmer Encyclopedia of Chemical Technology, 4th Edition, John Wiley and Sons, 18, 592- 602.

[3] Gao, J., Ellis, L.B. and Wackett, L.P. (2010) The University of Minnesota Biocatalysis/Biodegradation Database: Improving Public Access. Nucleic Acids Research, 38, D488-D491. http://dx.doi.org/10.1093/nar/gkp771

[4] Peng, F., Wang, H., Yu, H. and Chen, S. (2006) Preparation of Aluminum Foil-Supported Nano-Sized ZnO Thin Films and Its Photocatalytic Degradation to Phenol under Visible Light Irradiation. Materials Research Bulletin, 41, 2123-2129. http://dx.doi.org/10.1016/j.materresbull.2006.03.029

[5] Ruiz-Ordaz, N., Hernández-Manzano, E., Ruiz-Lagúnez, J., Cristiani-Urbina, E. and GalíndezMayer, J. (1998) Growth Kinetic Model That Describes the Inhibitory and Lytic Effects of Phenol on Candida tropicalis Yeast. Biotechnology Progress, 14, 966-969. http://dx.doi.org/10.1021/bp980095x

[6] Mörsen, A. and Rehm, H.J. (1990) Degradation of Phenol by a Defined Mixed Culture Immobilized by Absorption on Activated Carbon and Sintered Glass. Applied Microbiology and Biotechnology, 33, 209-212. http://dx.doi.org/10.1007/BF00176526

[7] Gerginova, M., Manasiev, J., Shivarova, N. and Alexieva, Z. (2007) Influence of Various Phenolic Compounds on Phenol Hydroxylase Activity of a Trichosporon cutaneum Strain. Zeitschrift für Naturforschung C, 62, 83-86. http://dx.doi.org/10.1515/znc-2007-1-215

[8] Nakagawa, H., Inoue, H. and Takeda, Y. (1963) Characteristics of Catechol Oxygenase from Brevibacterium fuscum. The Journal of Biochemistry, 54, 65-74.

[9] Abd El-Zaher, E.H., Mahmoud, Y.A.G. and Aly, M.M. (2011) Effect of Different Concentrations of Phenol on Growth of Some Fungi Isolated from Contaminated Soil. African Journal of Biotechnology, 10, 1384-1392.

[10] Nagamani, A., Soligala, R. and Lowry, M. (2009) Isolation and Characterization of Phenol 
Degrading Xanthobacter flavus. African Journal of Biotechnology, 8, 5449-5453.

[11] John, G.H., Sneath, P.H., Krieg, N.R., Holt, J.G. and Holt, J.G. (2000) Bergey's Manual of Determinative Bacteriology. 9th Edition, Lippincott Williams and Wilkins, New York.

[12] Sivaraj, R., Dorthy, C.A.M. and Veneckatesh, R. (2011) Isolation, Characterization, and Growth Kinetics of Bacteria Metabolizing Textile Effluent. Journal of Bioscience and Technology, 2, 324-330.

[13] Tork, S., Aly, M.M., Alakilli, S.Y. and Al-Seeni, M.N. (2013) Production and Characterization of Thermostable Xylanase from Bacillus subtilis XP10 Isolated from Marine Water. African Journal of Biotechnology, 12, 780-790.

[14] Aly, M.M., Tork, S. and Alakilli, S.Y. (2011) Molecular Characterization of Chitiniolytic Bacillus pumilus Isolated from Marine Habitats and Enhancement of Chitinase Production by Mutation. Univ Scholar in Biotechnol, 1, 14-21.

[15] Weisberg, W.G., Barns, S.M., Pelletier, D.A. and Lane, D.J (1991) 16S Ribosomal DNA Amplification for Phylogenetic Study. Journal of Bacteriology, 173, 697-703.

[16] Yang, R.D. and Humphery, A.E. (1975) Dynamic and Steady Sate Studies of Phenol Biodegradation in Pure and Mixed Cultures. Biotechnology and Bioengineering, 17, 1211-1235. http://dx.doi.org/10.1002/bit.260170809

[17] Neufeld, R.D. and Poladino, S.B. (1985) Comparision of 4-Aminoantipyrine and Gas Chromatography Techniques for Analysis of Phenol Compound. Journal of the Water Pollution Control Federation, 27, 1040-1044.

[18] APHA (American Public Health Association) (1992) Standard Methods for the Examination of Water and Wastewater. 18th Edition, APHA, Washington DC.

[19] Mohd, T. and Piakong, L. (2006) The Performance of Phenol Biodegradation by Candida Tropicalis RETL-Crl Using Batch and Fed Batch Fermentation Techniques. Ph.D. Thesis, University Teknologi Malaysia.

[20] Nair, C.I., Jayachandran, K. and Shashidhar, S. (2008) Biodegradation of Phenol. African Journal of Biotechnology, 7, 4951-4958.

[21] Mohite, B.V., Jalgaonwala, R.E., Pawar, S. and Morankar, A. (2010) Isolation and Characterization of Phenol Degrading Bacteria from Oil Contaminated Soil. Innovative Romanian Food Biotechnology, 7, 61-65.

[22] Nilotpala, P. and Ingle, A.O. (2007) Mineralization of Phenol by Serratia plymuthica Strain GC Isolated from Sludge Sample. International Biodeterioration \& Biodegradation, 60, 103 108. http://dx.doi.org/10.1016/j.ibiod.2007.01.001

[23] Tallur, P., Megadi, V., Kamanavalli, C. and Ninnekar, H. (2006) Biodegradation of p-Cresol by Bacillus sp. Strain PHN 1. Current Microbiology, 53, 529-533. http://dx.doi.org/10.1007/s00284-006-0309-x

[24] Hasan, S.A. and Jabeen, S. (2015) Degradation Kinetics and Pathway of Phenol by Pseudomonas and Bacillus Species. Biotechnology \& Biotechnological Equipment, 29, 45-53. http://dx.doi.org/10.1080/13102818.2014.991638

[25] Borghei, S.M. and Hosseini, S.H. (2004) The Treatment of Phenolic Wastewater Using a Moving Bed Biofilm Reactor. Process Biochemistry, 39, 1177-1181. http://dx.doi.org/10.1016/S0032-9592(02)00195-4

[26] Atsushi, S., Yasushi, I. and Arata, K. (2006) Aerobic and Anaerobic Bio Degradation of Phenol Derivatives in Various Paddy Soils. Science of the Total Environment, 367, 979-987. http://dx.doi.org/10.1016/j.scitotenv.2006.01.031

[27] Shawabkeh, R., Khaled, M. and Khleifat, L. (2007) Rate of Biodegradation of Phenol by 
Klebsiella oxytoca in Minimal Medium and Nutrient Broth Conditions. Bioremediation Journal, 11, 13-19. http://dx.doi.org/10.1080/10889860601185830

[28] Khleifat, L. and Khaled, M. (2007) Biodegradation of Phenol by Actinobacillus sp. Mathematical Interpretation and Effect of Some Growth Conditions. Bioremediation Journal, 11, 103-112. http://dx.doi.org/10.1080/10889860701429328

[29] Annadurai, G., Balan, M.S. and Murugesan, T. (2000) Design of Experiments in the Biodegradation of Phenol Using Immobilized Pseudomonas pictorium (NICM-2077) on Activated Carbon. Bioprocess Engineering, 22, 101-107.

[30] Annadurai, G., Rajesh Babu, S., Mahesh, K.P.O. and Murugesan, T. (2000) Absorption and Biodegradation of Phenol by Chitosan Immobilized Pseudomonas putida (NICM-2174). Bioprocess Engineering, 22, 493-501. http://dx.doi.org/10.1007/s004499900092

[31] Nair, I.C., Jayachandran, K. and Shankar, S. (2007) Treatment of Paper Factory Effluent Using a Phenol Degrading Alcaligenes sp. Under Free and Immobilized Condition. Bioresource Technology, 98, 714-716. http://dx.doi.org/10.1016/j.biortech.2006.02.034

Submit or recommend next manuscript to SCIRP and we will provide best service for you:

Accepting pre-submission inquiries through Email, Facebook, LinkedIn, Twitter, etc. A wide selection of journals (inclusive of 9 subjects, more than 200 journals)

Providing 24-hour high-quality service

User-friendly online submission system

Fair and swift peer-review system

Efficient typesetting and proofreading procedure

Display of the result of downloads and visits, as well as the number of cited articles Maximum dissemination of your research work

Submit your manuscript at: http://papersubmission.scirp.org/

Or contact aim@scirp.org 